\title{
Analysis and Design of Web Tapered Beams and Columns using Finite Element Analysis in Portal Frame Buildings
}

\author{
D.T. Lamkhade ${ }^{1}$ \\ ${ }^{1}$ M.E Civil-Structure Student, \\ Department of Civil Engineering, \\ JSPM's Rajarshi Shahu College Of Engineering \\ Tathawade, \\ Pune-411033, India
}

\author{
G.S. Wayal ${ }^{2}$ \\ ${ }^{2}$ Assistant Professor, \\ Department of Civil Engineering, Engineering, \\ JSPM's Rajarshi Shahu College Of Engineering \\ Tathawade, \\ Pune-411033, India
}

\author{
M. R.Sharma ${ }^{3}$ \\ ${ }^{3}$ Associate Professor, \\ Department of Civil Engineering, Engineering, \\ JSPM's Rajarshi Shahu College Of Engineering Tathawade, \\ Pune-411033, India
}

\begin{abstract}
A need is identified to introduce web-tapered portal frames to Indian conditions and practices, due to the apparent financial advantages and the unstable supply of hotrolled members locally. This study will bring together various aspects that need to be considered for the design of web-tapered portal frames and review if this method of construction is safe and worth pursuing as an alternative to conventional building techniques. The present investigation aims at comparison of conventional steel building and building. In this investigation analysis of and design of web tapered portal frames building and conventional steel building will be carried out for spans like $20 \mathrm{~m}$ using computer software Staad Pro v8i. 11 Web tapered steel portal frames is ideal for construction in remote and hilly areas.
\end{abstract}

Keywords-Web-tapered portal frames, Conventional Steel building, Staad Pro v8i.

\section{INTRODUCTION}

To achieve greater economy in material use, web-tapered steel members, where deeper cross-sections are used within the regions subjected to larger internal forces, are commonly employed within steel structures. However, the methods provided in current structural steel design specifications for the instability assessment of web-tapered steel members are based largely on those developed for prismatic steel members, often leading to overly conservative estimations of their ultimate strengths and thus limiting the efficiency gains achieved through their use.

\section{A. Objectives of the Present Study}

1.Create a structural optimization algorithm capable of finding the lightest possible frame, when subjected to various load combinations and design constraints.

2.Confirm the reported material savings potential of webtapered portal frames designed with Finite element Analysis method against conventional portal frames.

\section{B. Web tapered portal frames}

Web tapered portal frames are on an average 30\% lighter through efficient use of steel. Primary members are tapered built up sections, with large depths in the ares of highest stress. $\mathrm{n}$ this type of buildings all the structural elements are designed as per the bending moment diagram obtained. According to the bending moment diagram the steel sections are tapered. The specimens are manufactured at the factories as per the customers

requirement and then it is transported to the site. At the site by proper cutting and welding erection process is completed.

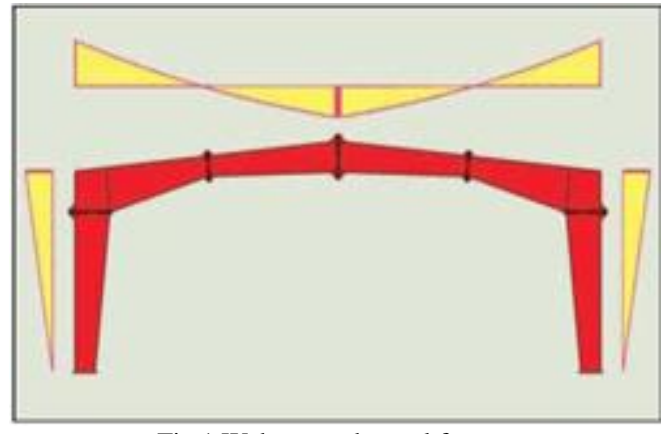

Fig.1 Web tapered portal frames

\section{Advantages of Web tapered Steel portal frames}

There are many advantages of web tapered steel portal frames which are as follows:

1.Quality control is the main advantage as all the structural member are engineered beforehand, standards of different codes also taken into consideration and these components are made in factory under the supervision of quality control Engineer.

2.Lower cost due to the saving in design, manufacturing and on-site erection cost.

3.Minimizing time of construction due to the use of software for design of the structural components.

4.Low maintenance due to use of standard quality of paints over steel members, which increases the ability to withstand and finally the maintenance cost will be low as compare to conventional building

5.Quick erection, as all the members are pre manufactured and skilled labor is used for connections of different components 
6.Warranty on Web tapered steel portal frames, mostly warranty period of 20 years given by manufactures for Web tapered steel portal frames.

\section{Conventional Steel Buildings}

Primary steel members are selected from standard hot rolled I section, which are, in many segments of the members, heavier than what is actually required by design. Members have constant cross sections regardless of the varying magnitude of the local stresses along the member length. Steel has many advantages like ductility, flexibility, strength etc. because of this factor they are more stable and steel offers high speed for the construction from the start of work. Usually for conventional steel buildings hot rolled structural members are used. In CSB all the steel members are fabricated at the manufacturing unit and transported to the site. By welding and cutting erection process is done. Trusses are the examples of conventional steel buildings.

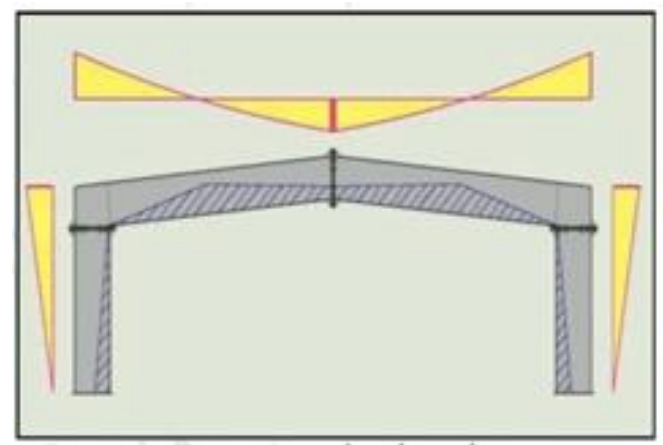

Fig.2 Conventional Steel Buildings

II. PROBLEM STATEMENT

A. Problem Statement of web tapered steel portal frames buildings and conventional steel buildings:

Long span column free structures are most essential in any type of industrial structure and web tapered steel portal frames fulfil this requirement along with reduced time and cost as compared to conventional structures. In this project range of spans will be decided for which web tapered steel portal frames can be provided economically. A comparative study of web tapered steel portal frames buildings and conventional steel building for spans $20 \mathrm{~m}$ is to be carried out.

\section{Conventional Steel Building Structure Parameters}

TABLE No 1 CONVENTIONAL STEEl BUILDING STRUCTURE PARAMETERS

\begin{tabular}{|c|c|c|}
\hline Sr. No & Type of building & Industrial building \\
\hline 1 & Type of structure & $\begin{array}{c}\text { Single storey industrial } \\
\text { structure }\end{array}$ \\
\hline 2 & Location & Pune \\
\hline 3 & Area of building & $800 \mathrm{~m}^{2}$ \\
\hline 4 & Eave height & $5.5 \mathrm{~m}$ \\
\hline 5 & Span width & $10 \mathrm{mo}$ 's \\
\hline 6 & Number of bays & $4 \mathrm{~m}$ \\
\hline 7 & Single bay length & fixed \\
\hline 8 & Total bay length & $21.8^{0}$ \\
\hline 9 & $\begin{array}{c}\text { Support condition } \\
\text { (conventional steel } \\
\text { buildings) }\end{array}$ & $\begin{array}{c}\text { Conventional steel } \\
\text { building roof slope }\end{array}$ \\
\hline 10 & Column & ISMB 400 \\
\hline 11 & \multicolumn{2}{c}{} \\
\hline
\end{tabular}

\begin{tabular}{|c|c|c|}
\hline 12 & Bottom chord & ISA-2L-90X90X10 \\
\hline 13 & Top Rafter chord & ISA-2L-90X90X10 \\
\hline 14 & $\begin{array}{c}\text { Vertical and inclined } \\
\text { section }\end{array}$ & ISA-2L-80X80X8 \\
\hline 15 & Purlin & ISMC200 \\
\hline
\end{tabular}

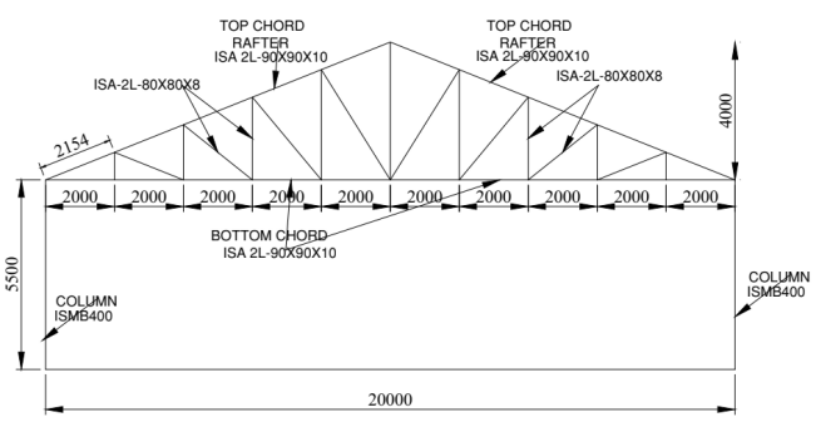

Fig.3 Elevation of Conventional steel building

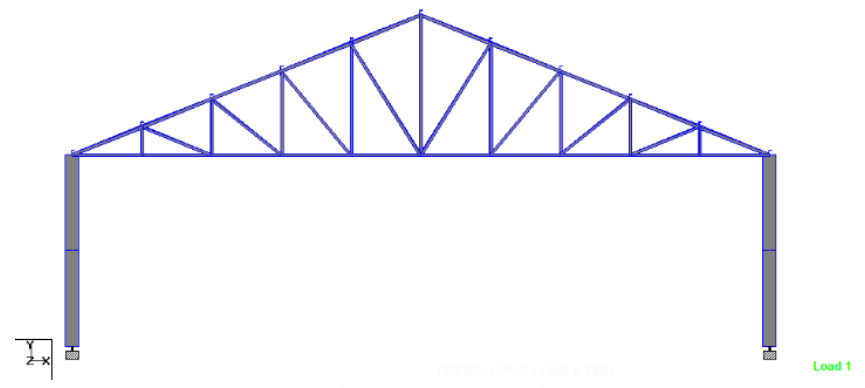

Fig.4 Staad-Pro Generated frame Elevation of Conventional steel building

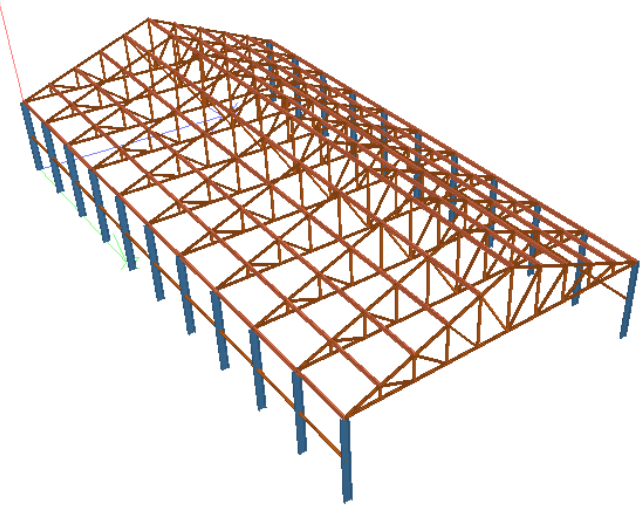

Fig. 5 Staad-Pro Generated 3D View of Conventional steel building

\section{Web tapered portal frames structure parameters}

TABLE NO 2 WEB TAPERED PORTAL FRAMES STRUCTURE PARAMETERS

\begin{tabular}{|c|c|c|}
\hline Sr. No & Type of building & Industrial building \\
\hline 1 & Type of structure & $\begin{array}{c}\text { Single storey industrial } \\
\text { structure }\end{array}$ \\
\hline 2 & Location & Pune \\
\hline 3 & Area of building & $800 \mathrm{~m}^{2}$ \\
\hline 4 & Eave height & $5.5 \mathrm{~m}$ \\
\hline 5 & Span width & $20 \mathrm{~m}$ \\
\hline 6 & Number of bays & 10 No's \\
\hline 7 & Single bay length & $4 \mathrm{~m}$ \\
\hline 8 & Total bay length & $40 \mathrm{~m}$ \\
\hline 9 & Support condition & fixed \\
\hline 10 & $\begin{array}{c}\text { (Web tapered portal } \\
\text { frames) roof slope }\end{array}$ \\
\hline
\end{tabular}




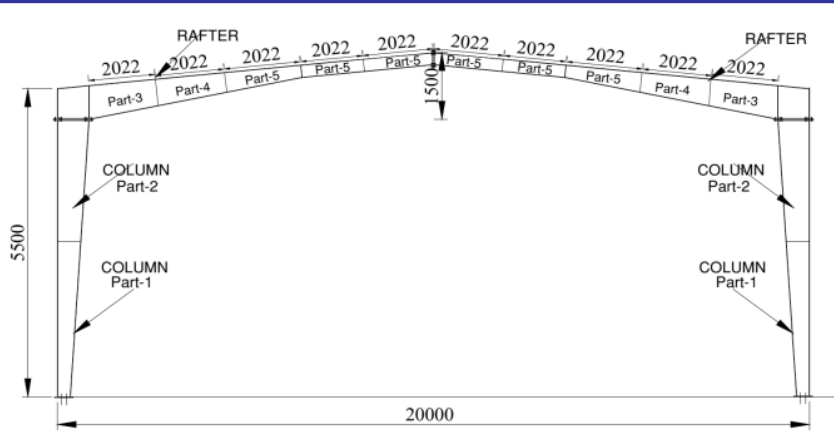

Fig.6 Elevation of Web tapered steel portal frames.

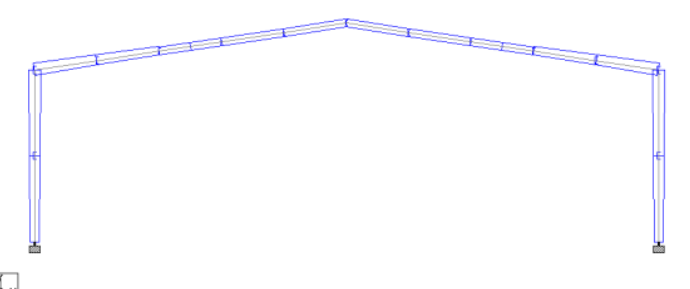

Fig. 7 Staad-Pro Generated Elevation of Web tapered steel portal frames

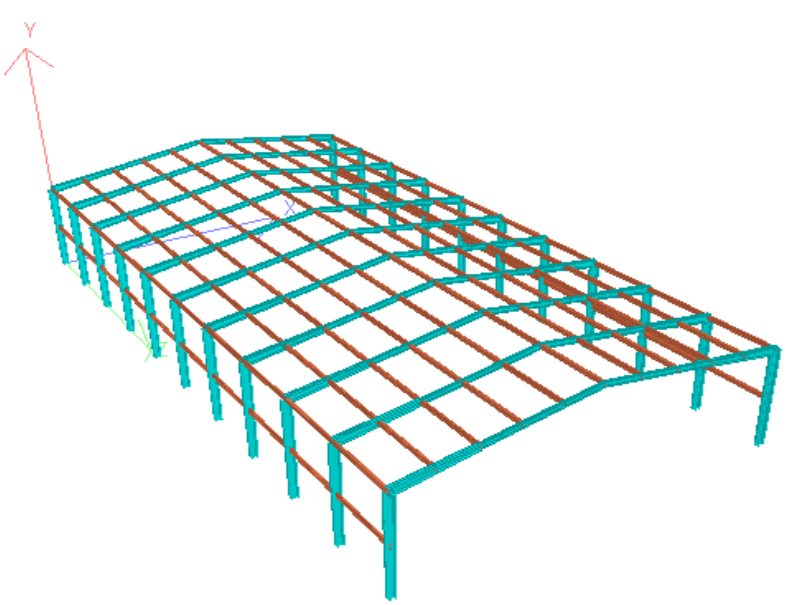

Fig.8 Staad-Pro Generated 3D View of Web tapered steel portal frames

\section{RESULTS AND DISCUSSION}

A. Maximum deflection (in $\mathrm{mm}$ ) at centre for $1.5(D L+L L)$ Maximum deflection at center for Web tapered portal frames and Conventional Steel Buildings by using staad pro software

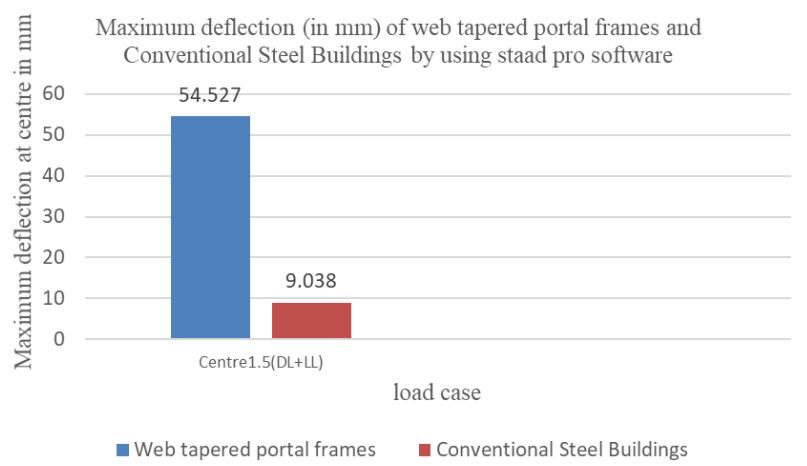

Fig.9 Maximum deflection (in $\mathrm{mm}$ ) of web tapered portal frames and Conventional Steel Buildings by using staad pro software

\section{B. Weight of Steel (Steel Take-Off) for Purlin in kg}

Weight of Steel (Steel Take-Off) for Purlin of Web tapered portal frames and Conventional Steel Buildings by using staad pro software.

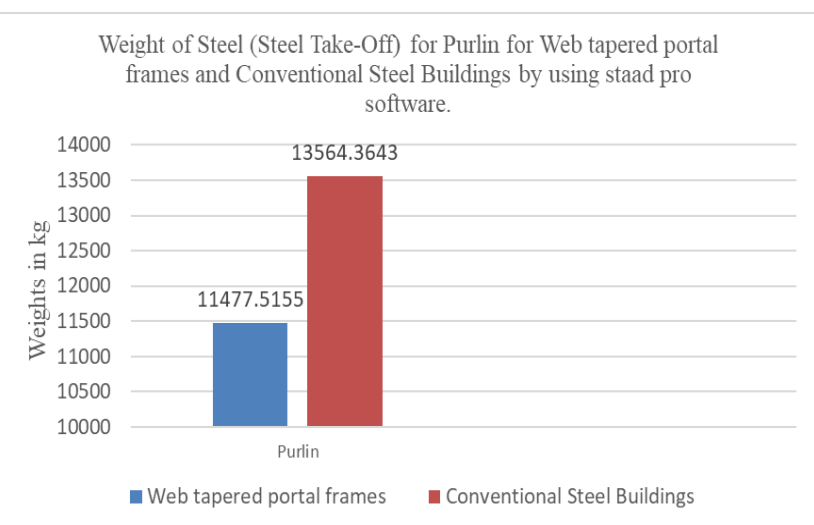

Fig.10 Weight of Steel (Steel Take-Off) for Purlin of Web tapered portal frames and Conventional Steel Buildings

\section{Weight of Steel (Steel Take-Off) for Column in kg}

Weight of Steel (Steel Take-Off) for Column of Web tapered portal frames and Conventional Steel Buildings by using staad pro software.

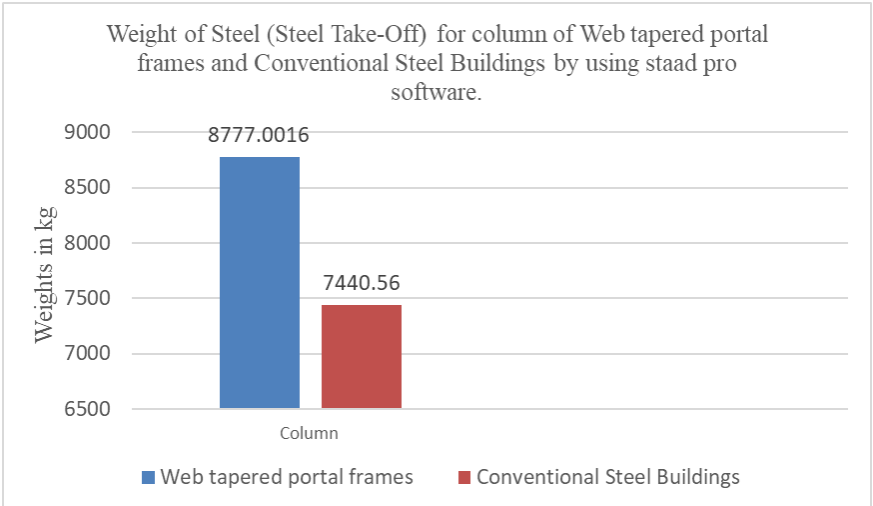

Fig.11 Weight of Steel (Steel Take-Off) for column of Web tapered portal frames and Conventional Steel Buildings

\section{Weight of Steel (Steel Take-Off) for rafter, vertical and inclined members in $\mathrm{kg}$}

Weight of Steel (Steel Take-Off) for rafter, vertical and inclined members in $\mathrm{kg}$ of Web tapered portal frames and Conventional Steel Buildings by using staad pro software.

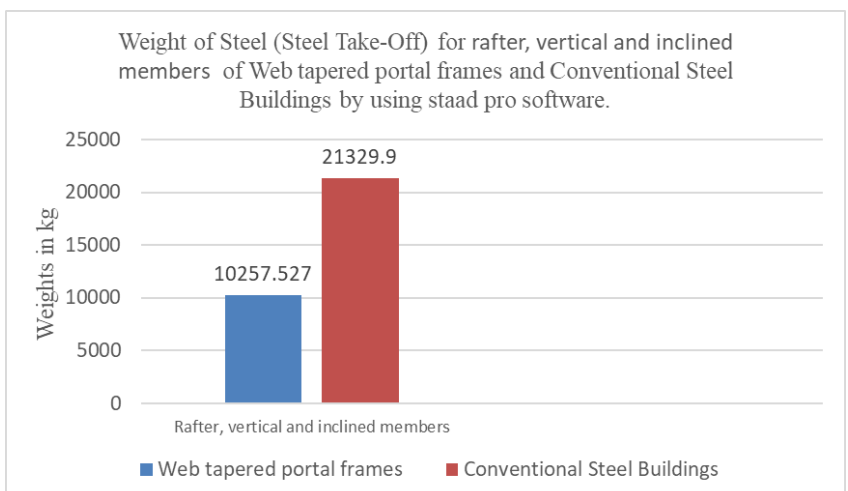

Fig.12 Weight of Steel (Steel Take-Off) for rafter, vertical and inclined members of Web tapered portal frames and Conventional Steel Buildings 


\section{E. Weight of Steel (Steel Take-Off) for tie member to column in $\mathrm{kg}$}

Weight of Steel (Steel Take-Off) for tie member to column in $\mathrm{kg}$ of Web tapered portal frames and Conventional Steel Buildings by using staad pro software.

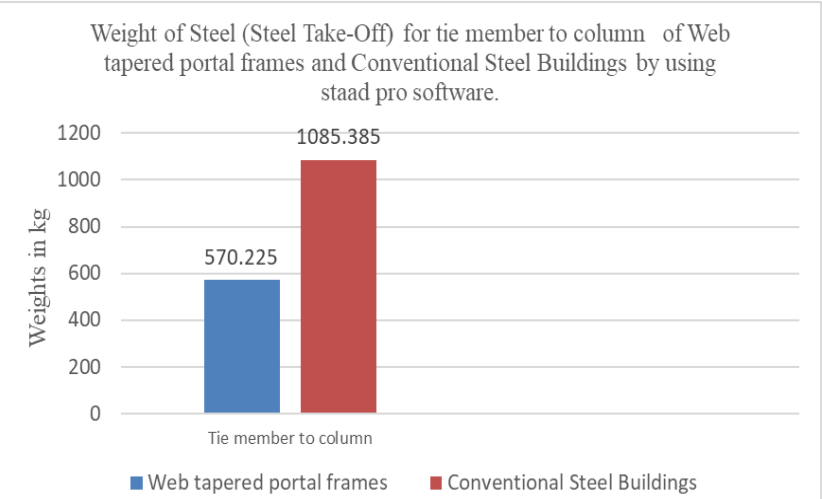

Fig.13 Weight of Steel (Steel Take-Off) for tie member to column in $\mathrm{kg}$ of Web tapered portal frames and Conventional Steel Buildings

\section{F. Total Weight of Steel (Steel Take-Off) in $\mathrm{kg}$}

Total Weight of Steel (Steel Take-Off) in kg of Web tapered portal frames and Conventional Steel Buildings by using staad pro software.

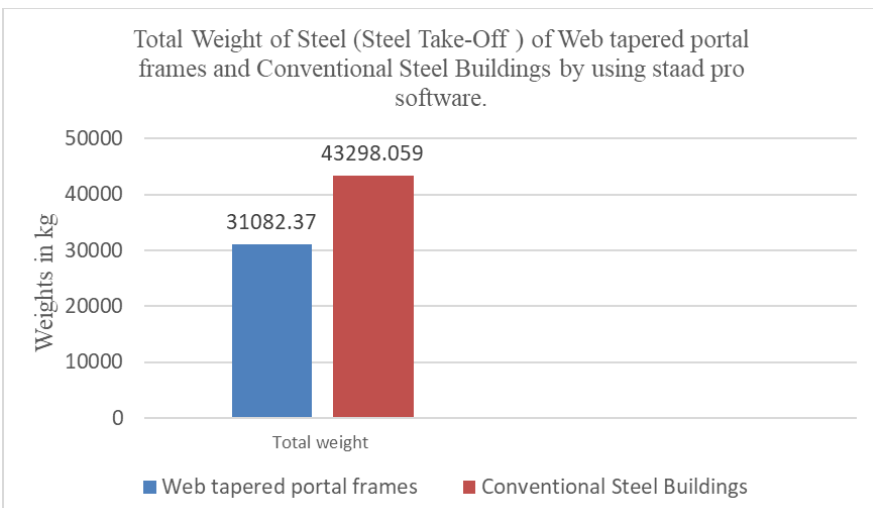

Fig.14 Total Weight of Steel (Steel Take-Off) in kg of Web tapered portal frames and Conventional Steel Buildings

\section{G. Total Reactions in $k N$ for $1.5(D L+L L)$}

Total Reactions in $\mathrm{kN}$ of Web tapered portal frames and Conventional Steel Buildings by using staad pro software.

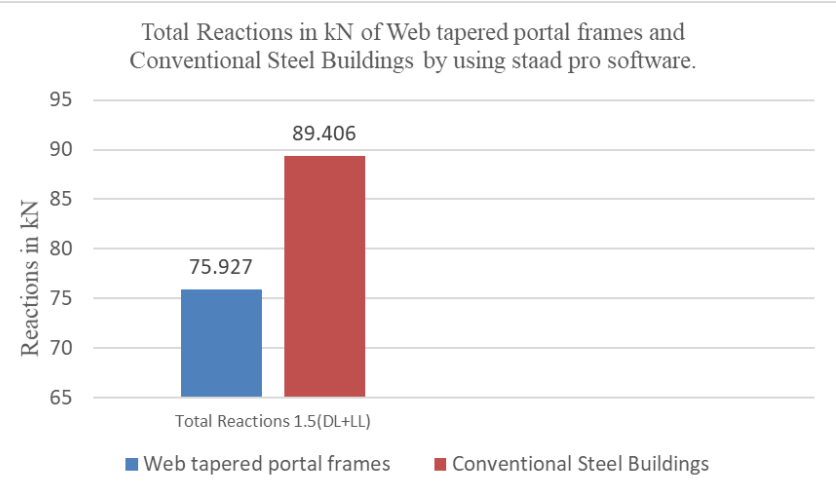

Fig.15 Total Reactions in kN of Web tapered portal frames and Conventional Steel Buildings.

\section{CONCLUSIONS}

Now a days Web tapered steel portal frames concept has been very successful and well established

1.The Maximum deflection (in $\mathrm{mm}$ ) of web tapered portal frames is more $83.42 \%$ than of Conventional Steel Buildings. 2.The Weight of Steel (in $\mathrm{kg}$ ) of web tapered portal frames is less $15.38 \%$ than of Conventional Steel Buildings.

3.The Weight of Steel (in $\mathrm{kg}$ ) for column of web tapered portal frames is more $15.22 \%$ than of Conventional Steel Buildings. 4.The Weight of Steel (in $\mathrm{kg}$ ) for rafter, vertical and inclined members of web tapered portal frames is more $15.22 \%$ than of Conventional Steel Buildings.

5.The Total Weight of Steel (in $\mathrm{kg}$ ) in $\mathrm{kg}$ of web tapered portal frames is less $28.21 \%$ than of Conventional Steel Buildings.

6.The Total Reactions in $\mathrm{kN}$ of web tapered portal frames is less $15.076 \%$ than of Conventional Steel Buildings.

7.Web tapered steel portal frames construction reduces the weight of building than conventional steel structures

8.It reduces the amount of steel requirement, reduction in dead load reduces the size of foundation

9.Web tapered steel portal frames construction is 30 to $40 \%$ faster than conventional steel structures.

10.Provide good insulation effect and would highly suitable for a tropical country like India.

11.Web tapered steel portal frames is ideal for construction in remote and hilly areas.

\section{REFERENCES}

[1] S. Saranya, Shallini.P. S, "Comparison of Structural Elements of a PreEngineered Building in Two Different Wind Zone Area”, International Research Journal of Engineering and Technology, Volume: 06 Issue: 05 May 2019.

[2] Shalu Assis, "Analysis of PEB structures and comparison with conventional steel

[3] buildings with varying parameters", International Research Journal of Engineering and Technology, Volume: 06 Issue: 05 May 2019

[4] Deepti D. Katkar, N.P.Phadtare, "Comparative Study of an Industrial Pre - Engineered Building with Conventional Steel Building”, International Research Journal of Engineering and Technology, Volume: 05 Issue: 10 | Oct 2018.

[5] Sangita C. Dike, Sandip. A. Karale, "Comparative Analysis of Multistorey Structure into RCC and PEB" IJRAR- International Journal of Research and Analytical Reviews, Volume 5 I Issue 3 I July - Sept 2018.

[6] Tabish Izhar, Juthika Nayak, Neha Mumtaz, "Comparative Study between Pre-Engineered RCC Structure and Usual RCC Structure", International Journal for Scientific Research \& Development Vol. 5, Issue 02, 2017

[7] Sachin B. Chavanke, Kanhaiya K. Tolani, "A Comparative Study of Analysis and Design of Pre-engineered Building and Conventional Steel Building for a Polymer Factory" IJSRD - International Journal for Scientific Research \& Development| Vol. 5, Issue 05, 2017 | ISSN (online): 2321-0613

[8] Bhagate et.al, "Comparative Study of Conventional Steel Building and Pre-engineered Building, International Journal of Engineering Technology, Management and Applied Sciences, April 2017, Volume 5, Issue 4.

[9] Vimala et.al, "Analysis and Design of Pre - Engineered Building for Vehicle Parking Shed", International Journal of Advanced Research in Engineering \& Management, Vol. 03-Issue 11 -2017-43-65

[10] Tejal Patil and Nagesh L Shelke, "Structural Analysis of a Cantilever Beam with Tapered Web Section through Fea" Journal of Steel Structures \& Construction, Volume 2 - Issue 2 • 2016.

[11] L Maria Subashini and Shamini Valentina, "Comparative Study of PreEngineered and

[12] Conventional Industrial Building”, Indian Journal of Science and Technology, Vol 8(32), November 2015 
[13] Pradeep V, Papa Rao G, "Comparative Study of Pre-Engineered and Conventional Industrial Building", International Journal of Engineering Trends and Technology (IJETT) - Volume 9 Number 1 - Mar 2014

[14] Sagar Wankhede, P. S. Pajgade, "Review Paper on Comparison of Conventional Steel Building \& Pre-Engineering Building", International Journal of Research in Advent Technology, Vol.2, No.5, May 2014

[15] G. Durga Rama Naidu, K. Srinivasa Vengala Rao, V. Divya Sri, M. Navakanth, G.V. Rama Rao, "Comparative Study of Analysis and Design of Pre-Engineered Buildings and Conventional Frames" International Journal of Engineering Research and Development, Volume 10, Issue 9 (September 2014), PP.33-41

[16] Milind Bhojkar, Milind Darade, "Comparison of Pre-Engineering Building and Steel Building with Cost and Time Effectiveness" IJISET - International Journal of Innovative Science, Engineering \& Technology, Vol. 1 Issue 10, December 2014.

[17] Jatin D. Thakar, P.G. Patel, "Comparative Study of Pre-Engineered Steel Structure by Varying Width of Structure", International Journal of Advanced Engineering Technology, July-Sept.,2013. Page-56-62

[18] IS 875:2015, "Design loads (other than Earthquake) for Buildings and Structures, Part 3-Wind Loads", Bureau of Indian Standards, New Delhi, India

[19] BIS 1161(1998), Steel tubes for structural purposes-specifications

[20] BIS 800 (2007), General Construction in Steel

[21] BIS 875 (1987) Part I, Code of practice for design loads (other than earthquakes) for buildings and structures (Dead Load)

[22] BIS 875(1987) Part II, Code of practice for design loads (other than earthquakes) for buildings and structures (Imposed Load)

[23] BIS 875(1987) Part III, Code of practice for design loads (other than earthquakes) for buildings and structures (Wind Load)

[24] Dr. B.C. Punmia., Dr. Ashok Kumar Jain., Dr. Arun Kumar Jain., "Design of Steel Structures", Second Edition, Lakshmi Publications (P) Ltd,

[25] Duggal, S.K., (2014). "Limit state Design of Steel Structures “, Tata McGraw-Hill Education.

[26] Subramanian, N., (2010). "Design of Steel Structures", Oxford Higher Education.

[27] IIT-Kharagpur, Design of Steel structures, "NPTEL online material for the students" 